\title{
THE DISPERSAL OF SATELLITE-TAGGED JUVENILE GYRFALCONS FROM AN AREA OF WIND-FARM DEVELOPMENT IN THE SWEDISH MOUNTAINS
}

\author{
Torgeir NygÅrd ${ }^{1}$, Ulla Falkdalen ${ }^{2}$, And Henri Engström ${ }^{3}$ \\ ${ }^{1}$ Norwegian Institute for Nature Research, Tungasletta 2, NO-7485 Trondheim, Norway. \\ E-mail: torgeir.nygard@nina.no \\ ${ }^{2}$ Project Gyrfalcon, Frösö-Berge 110, SE-832 96 Frösön, Sweden \\ ${ }^{3}$ Department of Population Biology and Conservation Biology, Uppsala University, \\ Norbyvägen 18d, SE-75236 Uppsala, Sweden
}

\begin{abstract}
We studied the dispersal of 14 juvenile Gyrfalcons (Falco rusticolus) from their nest sites in an area of wind-farm development in the central Swedish mountains by means of satellite telemetry from 2005 to 2010 . Their median age at tagging was estimated at 41 days. Their home ranges increased exponentially with time after leaving the nest. The median date for permanent dispersal $>5 \mathrm{~km}$ from the nest was August 21, at approximately 40 days after fledging. The median size of the pre-dispersal home range was $266 \mathrm{~km}^{2}$, but varied greatly. Females tended to disperse further than males. The initial dispersal was non-directional, but eventually at least four birds reached the Atlantic or Baltic coasts. The risk of collision with wind turbines is judged to be highest in the pre-dispersal period when birds roamed within $5 \mathrm{~km}$ from the nest, which has implications for choice of turbine sites. The high collision rates of ptarmigan (Lagopus spp.) with wind turbines, the main prey of Gyrfalcons, found in Norway indicate that depletion of prey stocks pose an additional risk. The data indicate a high first autumn mortality, and the tagging technique is discussed in this context. Received 8 April 2011, accepted 26 April 2011.
\end{abstract}

NYGÅRD, T., U. FALKDALEN, AND H. ENGSTRÖM. 2011. The dispersal of satellite-tagged juvenile Gyrfalcons from an area of wind-farm development in the Swedish mountains. Pages 161-170 in R. T. Watson, T. J. Cade, M. Fuller, G. Hunt, and E. Potapov (Eds.). Gyrfalcons and Ptarmigan in a Changing World, Volume II. The Peregrine Fund, Boise, Idaho, USA. http://dx.doi.org/10.4080/ gpcw.2011.0216

Key words: Gyrfalcon, Falco rusticolus, dispersal, Sweden, Norway, satellite telemetry, windfarms, ptarmigan.

CONCERNS ARE BEING RAISED in many parts of the world about raptor fatalities in wind-farm areas. Sweden is currently developing its wind-power to reduce $\mathrm{CO}_{2}$ emissions and gradually replace fossil fuel and nuclear power with renewable energy. Wind-farms are being built all over Sweden, including in the mountains. One farm of 12 2.5-MW turbines was recently built in a mountainous region in Jämtland, c. $63^{\circ} 45^{\prime} \mathrm{N}, 13^{\circ} 35^{\prime} \mathrm{E}$, in the breeding 


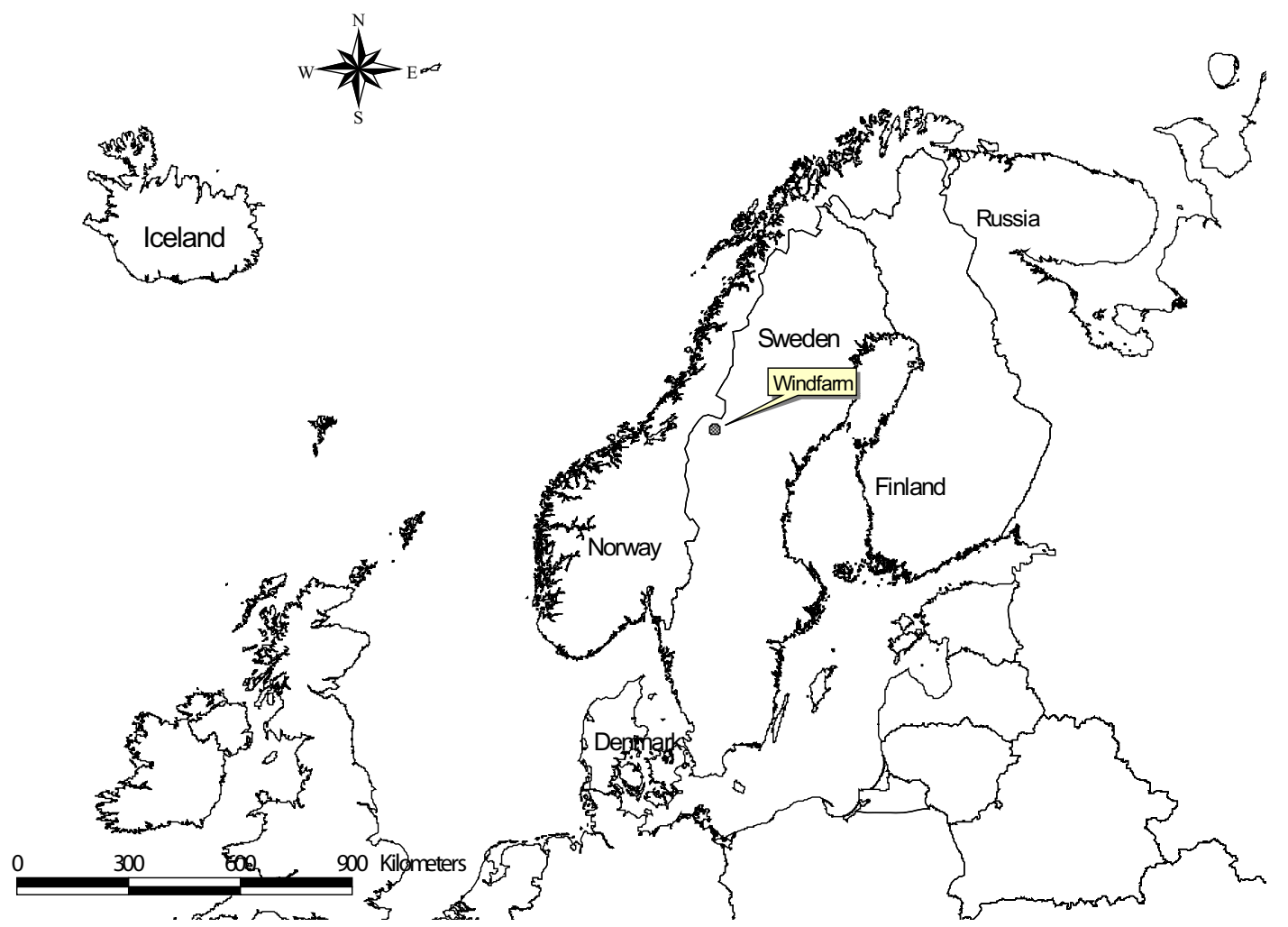

Figure 1. Map of northern Europe showing the position of Storrun wind-farm in Sweden, $63^{\circ} 45^{\prime} \mathrm{N}$, 133' $\mathrm{E}$.

habitat of Gyrfalcons (Falco rusticolus) (Figure 1). Raptors are among the bird species most vulnerable to collisions with wind turbines, and high fatality rates have been documented for broad-winged raptors such as eagles and buteos in the USA, but falcons are also regularly found killed (Smallwood and Karas 2009). In Germany, more than 50 falcons of four species have been found killed by wind turbines, together with 57 White-tailed Eagle (Haliaeetus albicilla), 146 Red Kite (Milvus milvus), and 186 Common Buzzard (Buteo buteo) (Illner 2011). Raptors of several species have been found killed by wind turbines in Sweden but the extent and geographical distribution is insufficiently studied. A preand post-wind-farm-construction study on Gyrfalcons breeding in the area surrounding
Storrun wind-farm in Sweden took place during 2005-2010, involving satellite-tagging of nestlings to study their movements in the vicinity of the turbines and their dispersal patterns.

Little is known about the dispersal of juvenile Gyrfalcons in Scandinavia, since very few recoveries of ringed birds have been made. Most of 17 juveniles ringed in Norway were recovered on the coast of Norway during their first year of life (Bakken et al. 2003). In Sweden, five out of seven recoveries (all of them juveniles in their first autumn) were from Norway, four of them from the coast (Fransson et al. 2001). Research in Alaska using satellite telemetry has shown wide dispersal of Gyrfalcons from the breeding area during their first 

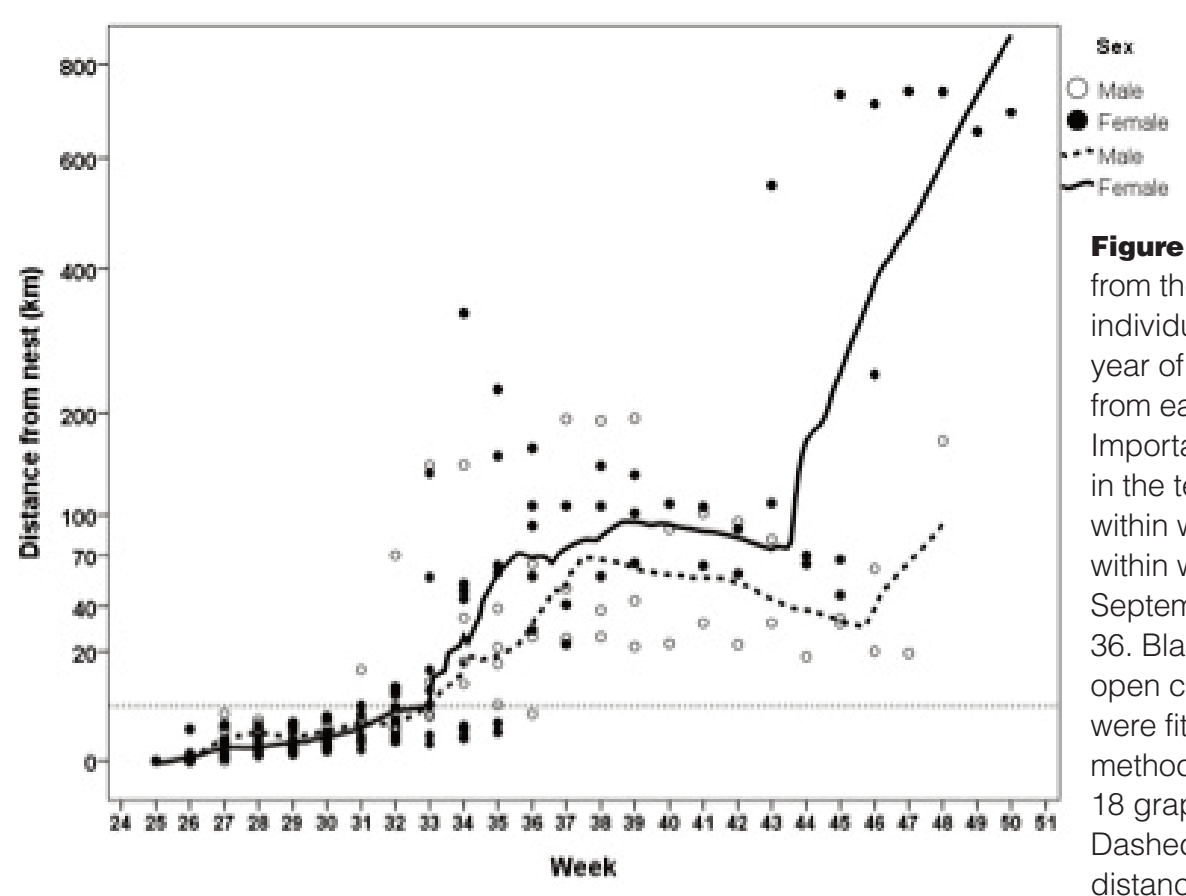

Figure 2. Median distances from the nest for each individual and week of the year of juvenile Gyrfalcons from east-central Sweden. Important dates referred to in the text: August 8 is within week 32, August 21 within week 34 , and September 7 within week 36. Black dots=females, open circles $=$ males. Lines were fitted by the Loess method in PASW Statistics 18 graphics module.

Dashed line indicates $5 \mathrm{~km}$ distance from the nest.

autumn (McIntyre et al. 2009). That study used conventional Argos platform terminal transmitters (PTT) with a location accuracy based on Doppler calculation that did not allow for a detailed study of the utilization area of juvenile Gyrfalcons in their early phases of dispersal. A study of Gyrfalcons satellite-tagged in Greenland showed wide ranging behavior of both adults and juveniles (Burnham 2007). The recent availability of light-weight GPS-PTT transmitters for birds made it possible for us to study in detail the movements of newly fledged juvenile Gyrfalcons throughout their dispersal period during their first autumn.

\section{METHODS}

The tagging took place in three areas, one 20$30 \mathrm{~km}$ away from the wind-farm (eight chicks), a second $80 \mathrm{~km}$ away (one chick), and a third c. $100 \mathrm{~km}$ away (five chicks). Six of the transmitters were solar-powered Argos GPS-PTTs (22-30 g), while eight were conventional Doppler-based Argos PTTs (18-30 g), all from
Microwave Telemetry, Inc., Columbia, MD 21045. The birds were sexed by measuring the mass, wing length, tail length, bill depth, bill length, tarsus width, tarsus depth, and length of hind claw. The nestlings were provisionally sexed in the field, and were later sexed using discriminant analysis of biometrics. Independent variables entered together confirmed the field classifications in all cases. Eight were sexed as females and six as males. Poole (1989) found that the growth rate of primary feather number seven and the middle rectrices were linear from day 11 to 40-42 days of age. Using an extended dataset, we compared the length of the $7^{\text {th }}$ primary $(\mathrm{P} 7)$ with the tail length in $\mathrm{mm}$ (TL), and they were highly correlated $(\mathrm{R}=$ $0.896, \mathrm{P}<0.001, \mathrm{n}=22$ ). We thus obtained the following formula for nestling age (NA):

$$
\mathrm{NA}=0.18^{*} \mathrm{TL}+14.2
$$

Using these calculations, the chicks were estimated to be c. $41( \pm 3)$ days old at the time of tagging, assuming growth rates were the same for both sexes (Poole 1989). 
Table 1. Dispersal data for 14 Gyrfalcons tagged with satellite transmitters as nestlings in Sweden.

\begin{tabular}{|c|c|c|c|c|c|c|c|c|c|c|}
\hline Id & Year & $\begin{array}{l}\text { Transmitter } \\
\text { type }\end{array}$ & Sex & $\begin{array}{l}\text { Age at } \\
\text { tagging } \\
\text { (days) }\end{array}$ & $\begin{array}{l}\text { First } \\
\text { dispersal } \\
\text { date } \\
>5 \mathrm{~km}\end{array}$ & $\begin{array}{l}\text { Permanent } \\
\text { dispersal } \\
\text { date } \\
>5 \mathrm{~km}\end{array}$ & $\begin{array}{l}\text { Age at } \\
\text { permanent } \\
\text { dispersal } \\
\text { (days) }\end{array}$ & $\begin{array}{l}\text { Length } \\
\text { of post- } \\
\text { fledging } \\
\text { period } \\
\text { (days) }^{1}\end{array}$ & $\begin{array}{l}\text { Pre- } \\
\text { dispersal } \\
\text { home } \\
\text { range } \\
\left(\mathrm{km}^{2}\right)\end{array}$ & $\begin{array}{l}\text { Maximum } \\
\text { distance } \\
\text { dispersed } \\
\text { from nest } \\
(\mathrm{km})\end{array}$ \\
\hline 57267 & 2010 & GPS & $F$ & 41 & $30 \mathrm{Jul}$ & 20 Aug & 93 & 43 & 3464 & 192 \\
\hline 95679 & 2009 & Argos & $\mathrm{M}$ & 39 & 04 Aug & $10 \mathrm{Sep}$ & 116 & 66 & 266 & 194 \\
\hline 67127 & 2007 & GPS & M & 39 & 05 Aug & 25 Aug & 91 & 41 & 1698 & 108 \\
\hline 95338 & 2009 & Argos & M & 39 & 08 Aug & 08 Aug & 73 & 23 & 22 & 145 \\
\hline 58955 & 2007 & Argos & F & 41 & 08 Aug & 19 Aug & 87 & 37 & 298 & 117 \\
\hline 58954 & 2005 & GPS & F & 42 & 08 Aug & 14 Aug & 90 & 40 & 69 & 341 \\
\hline 57285 & 2010 & Argos & $F$ & 44 & 10 Aug & 13 Aug & 89 & 39 & 186 & 259 \\
\hline 58956 & 2005 & Argos & M & 42 & 11 Aug & 15 Aug & 91 & 41 & 52 & 42 \\
\hline 57279 & 2010 & Argos & F & 41 & 17 Aug & 27 Aug & 100 & 50 & 88 & 740 \\
\hline 57277 & 2010 & Argos & M & 40 & 19 Aug & 22 Aug & 94 & 44 & 349 & 168 \\
\hline 57251 & 2010 & GPS & F & 42 & 25 Aug & 07 Sep & 112 & 62 & 2936 & 78 \\
\hline 95325 & 2009 & GPS & $F$ & 39 & a & & & & & $2.5^{\star}$ \\
\hline 67128 & 2007 & Argos & $\mathrm{M}$ & 41 & a & & & & & $5.2^{c \star}$ \\
\hline 86415 & 2008 & GPS & F & 40 & b & & & & & $2.5^{\star}$ \\
\hline Median & & & & 41 & 08 Aug & 20 Aug & 91 & 41 & 266 & 217 \\
\hline S.D. & & & & 1 & 7 days & 10 days & 12 & 12 & 1255 & 193 \\
\hline
\end{tabular}

${ }^{1}$ Assuming fledging at 50 days of age.

aNever dispersed.

bFound dead near nest site.

'Based on Argos class-1.

*Not included in median.

We used PASW Statistics 18 for statistics (CIBM Corporation, Somers, NY 10589), and ArcView v.3.3 (CESRI, Redlands, CA 923738100) for maps.

\section{Results}

The median date for the first excursion $>5 \mathrm{~km}$ from the nest was August $8(n=11, S D=7$ days), while the median date for permanent dispersal $>5 \mathrm{~km}$ without subsequent return was August $21(\mathrm{n}=11, \mathrm{SD}=10$ days, Figure 2, Table 1). This was 52 days after tagging (median value, $\mathrm{SD}=12$ ). Assuming a fledging age of 50 days (Poole and Bromley 1988), the birds spent a median of 41 days $(\mathrm{SD}=12)$ in the nest area after fledging before permanent dispersal, presumably being dependent on their parents for food. Three birds never dispersed; one of them was found dead, and two others probably died near the natal site, without recovery. Very few $(5.1 \%)$ movements more than $10 \mathrm{~km}$ from the nest were recorded before permanent dispersal, but some long movements with subsequent return occurred up to $86 \mathrm{~km}$, based on positions of Argos class-1 accuracy or better. The median age of permanent dispersal was estimated to be 93 days. All 


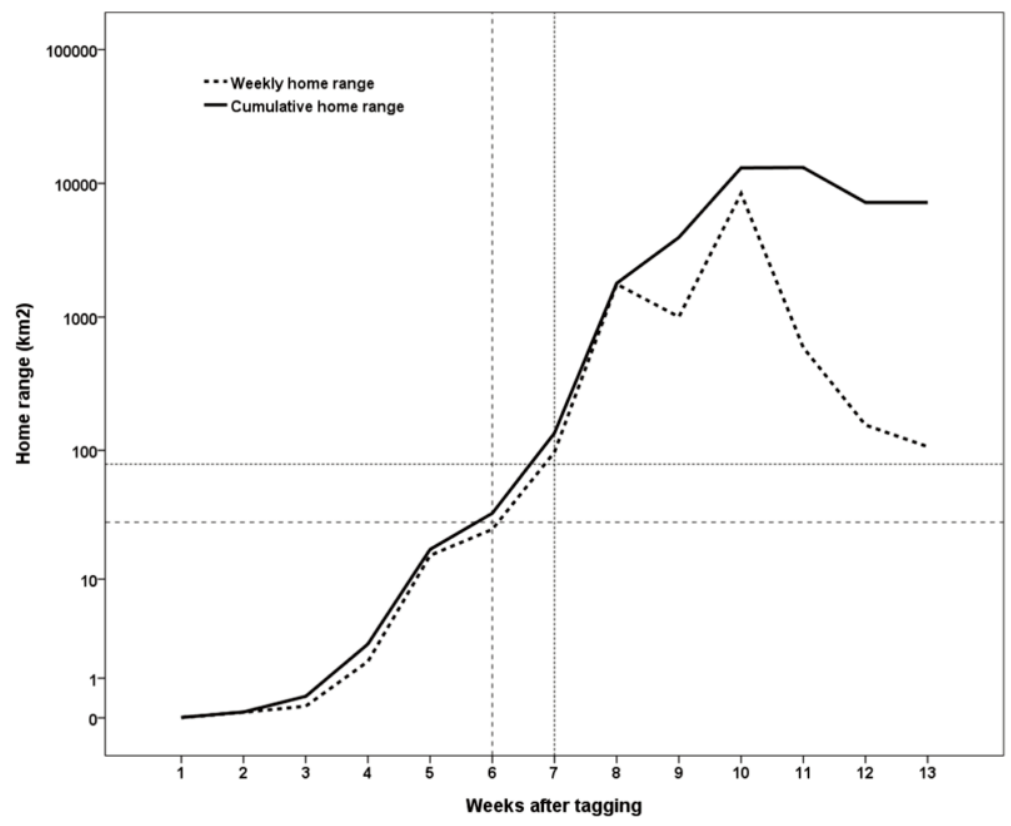

Figure 3. The median size of the home-range of six GPS-satellite tagged juvenile Gyfalcons in Sweden. The coarsely dashed line crosses the $28 \mathrm{~km}^{2}$ line (indicating an area equivalent to a circle with radius of $3 \mathrm{~km}$ ) at six weeks after tagging. The finely dashed line similarly indicates an area of 78.5 $\mathrm{km}^{2}$ (radius $=5 \mathrm{~km}$ ) being obtained at seven weeks after tagging. birds had permanently dispersed $>5 \mathrm{~km}$ from the wind-farm by September 7. No sex differences regarding permanent dispersal dates were found (U-test, $\mathrm{Z}=-.83, \mathrm{P}=0.86$ ). The median home-range of juveniles (100\% minimum convex polygon, $\mathrm{MCP}$ ) before permanent dispersal was $266 \mathrm{~km}^{2}$ (range 22-3464 $\mathrm{km}^{2}, \mathrm{n}=11, \mathrm{SD}=1255 \mathrm{~km}^{2}$ ).

The size of home ranges throughout the summer and autumn increased exponentially with time (Figure 3). Little difference was seen between cumulative and weekly home ranges until late in autumn when weekly home range area declined and cumulative range area remained little changed, presumably after juveniles settled down at their final destination. Only GPS PTT positions were used for these calculations, for their greater accuracy over conventional PTT Doppler-calculated positions. In this figure, we have indicated the time points when the home ranges constitute areas equivalent to circles with radii of 3 and $5 \mathrm{~km}$. The Swedish Ornithological Society (Sveriges Ornitologiska Förening, SOF) has recommended a $3-\mathrm{km}$ buffer zone as a precautionary measure around Gyrfalcon nest sites where no turbines should be built (see http://sofnet.org). Five km was used by us as an indicator of permanent dispersal. One should keep in mind that home ranges rarely are circular, but tend to follow landscape features such as mountain ridges, making them more elongated in shape. These home range sizes were obtained at median ages of c. 84 days, six weeks after tagging, and 91 days, seven weeks after tagging, respectively.

No GPS positions were closer than $7 \mathrm{~km}$ from the Storrun wind-farm during dispersal, while some Argos positions of lower accuracy (class1 or better) were closer, but less reliable (Figure 4). Although the Storrun area is good Willow Ptarmigan (Lagopus lagopus) habitat (the main prey of the falcons), the area is rather small, while the most extensive ptarmigan habitats are further north. To the south, there are more forests and lowlands. Only three juveniles were fitted with GPS transmitters in this area. When we plot all GPS-tagged individuals $(n=6)$ in a graph showing distance from nest by time of year (Figure 5), it seems 
clear that there are extensive movements in the vicinity of the nest during the dispersal period. A line is drawn in the graph to illustrate the 18 $\mathrm{km}$ distance; the distance of the nest closest to the Storrun windfarm. Not all juveniles with GPS tags were included in the graph.

Dispersal seemed to occur in any direction (Figure 6). At least four of the birds eventually reached the coast; one the Baltic Sea, one the North Sea, and two the Atlantic coast. Females dispersed further than males. A univariate ANOVA using the log median distance from the nest for each week of the year was significant for both sex and week (sex: $\mathrm{P}=0.025, \mathrm{~F}=$ 5.17, $\mathrm{df}=1$; week: $\mathrm{P}<0.001, \mathrm{~F}=37.9, \mathrm{df}=1$ ). The maximum recorded distance from the nest was $720 \mathrm{~km}$ for a female bird. This bird probably ended up on a boat in the North Sea off the southern tip of Norway, as her latest positions were from open water and somewhat erratic. Unfortunately, she was not recovered. Sightings have revealed that juvenile Gyrfalcons from Sweden can move all the way south to Denmark during winter (photo documentation of a ringed bird). The female bird that reached the Baltic Sea close to Umeå, Sweden, was seen hunting for pigeons and also photographed. Her last position was from an area of suburban character with much traffic, buildings, and overhead wires. Disappointingly, none of the satellite-tagged juveniles transmitted signals through the first winter. This may be indicative of high mortality in the first autumn, which may be expected from a species that matures early and has a relatively high annual productivity. Only one of the tagged birds has been recovered dead so far. Another transmitter emitting a VHF mortality signal was searched for in the field with a dog, but we were not able to find it. We believe that the bird had lost the transmitter, and it was hidden in the vegetation or between rocks in the rugged terrain.

The juvenile Gyrfalcons spent most of their time after dispersal in mountainous terrain. The dispersal patterns varied greatly. Most birds spent the period until the middle of

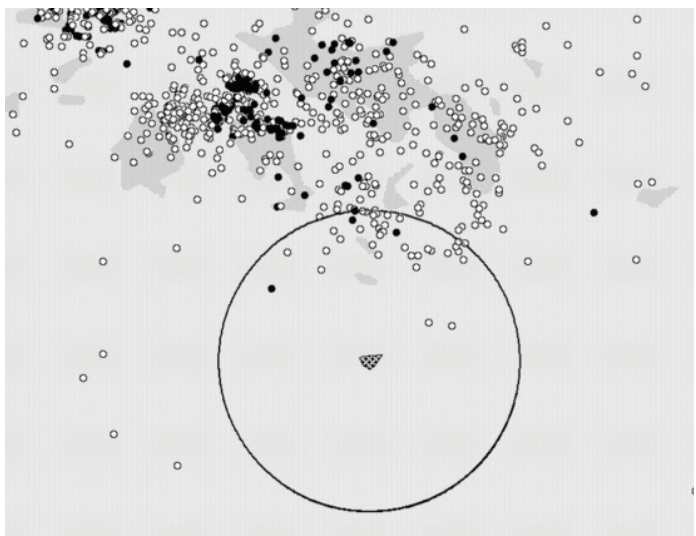

Figure 4. Positions of three GPS-tagged juvenile Gyrfalcons in the vicinity of Storrrun Windfarm. Open circles: Argos positions of class-1 or better, black dots: GPS positions. The circle has a $10-\mathrm{km}$ radius, and the hatched area in the middle is the actual area and position of the windfarm.

August exploring the immediate surroundings of the eyrie, but later moved on in a directionoriented fashion. However, much variation occurred. Figure 7 shows the post-dispersal movements of a female juvenile making two extensive circular movements in a rather large mountain expanse, but returning to the nesting area after each of them. Of 3,698 positions of Argos class- 1 or better, $2.6 \%$ were from $0-300$ $\mathrm{m}$ altitude, $70.2 \%$ from 300 to $900 \mathrm{~m}$, and $27.2 \%$ were from an altitude of 900 to $2100 \mathrm{~m}$. Below c. $300 \mathrm{~m}$, the habitat is mostly spruce/pine forests with farmlands at the lowest altitudes. In the altitudinal range of 300$900 \mathrm{~m}$, there is a zone of mixed broken forests of Norway Spruce (Picea abies), Scots Pine (Pinus sylvestris), and Mountain Birch (Betula pubescens ssp. tortuosa) interspersed with mires, bogs, and rocky outcrops in the lower parts, with an increasing dominance of mountain birch and willows with increasing altitude. Above $900 \mathrm{~m}$, scattered bushes of willow (Salix spp.) and Dwarf Birch (Betula nana) are the main woody species, and the landscape is of Alpine character. The Gyrfalcon nests were all situated between $700-1100 \mathrm{~m}$ of altitude. 


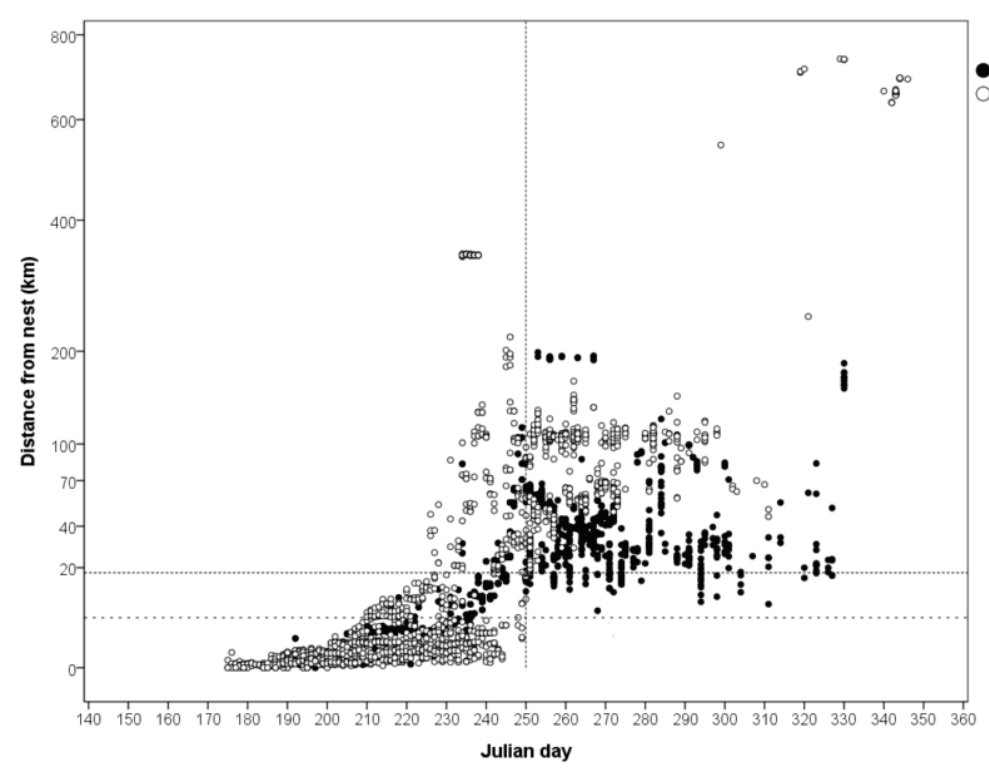

Sex

OFemale

Figure 5. Dispersal distances from the nests based on GPS positions of satellite-tagged juvenile Gyrfalcons during their first year of life in relation to Julian date. The lower horizontal line indicates $5 \mathrm{~km}$ (first dispersal), while the upper horizontal line indicates the nearest distance from one of the nests to the windfarm (18 $\mathrm{km})$. The vertical line shows the date at which all the juveniles had dispersed (September 7). Open circles $=$ females, filled circles $=$ males.

Figure 6.

Dispersal of 11 juvenile gyrfalcons satellite-tagged in the mountains of Jämtland, Sweden, 2005-2010.

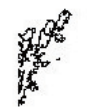

Black arrows=females, grey arrows=males.

No shading: Areas below $300 \mathrm{~m}$ asl.

Light shading: Areas between 300 and 900 $\mathrm{m}$ asl.

Dark shading: Areas above $900 \mathrm{~m}$ asl.

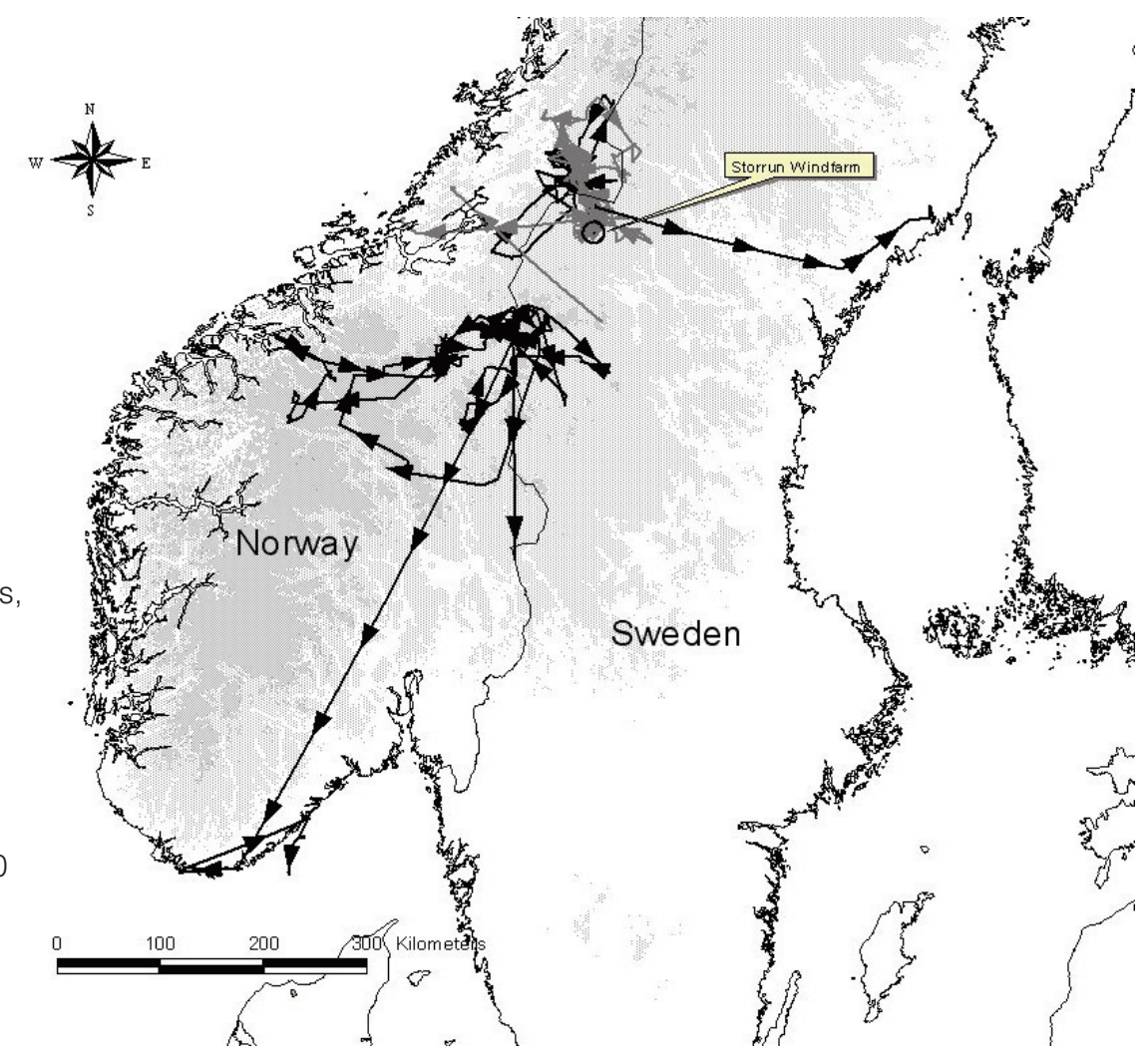


Figure 7. Dispersal movements of a female juvenile Gyrfalcon in the autumn of 2010. No shading: areas below $300 \mathrm{~m}$ asl. Light shading: areas between 300 and $900 \mathrm{~m}$ asl. Dark shading: areas above $900 \mathrm{~m}$ asl.

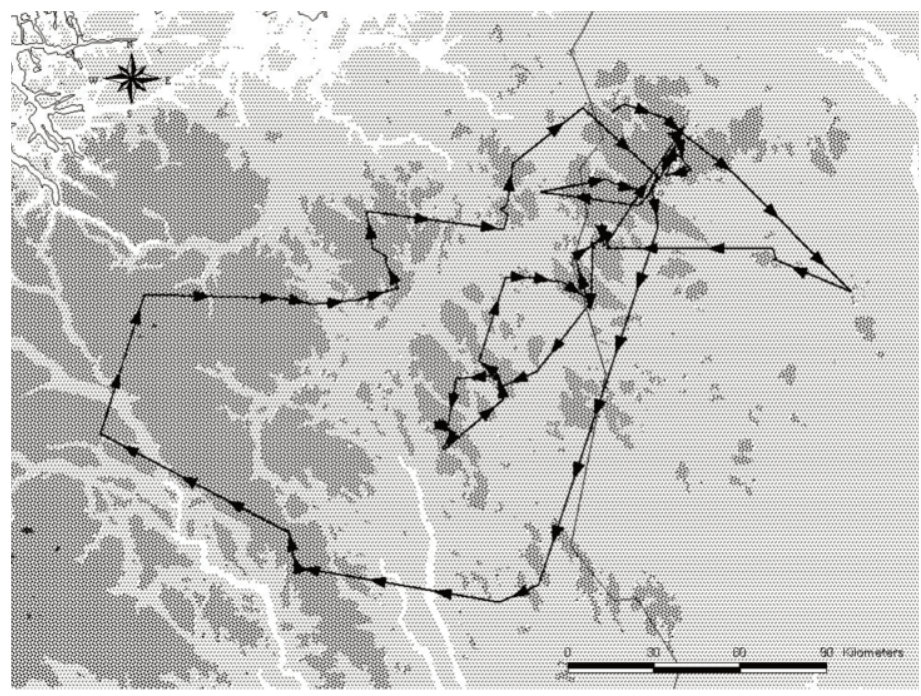

\section{Discussion}

After leaving the nest, juvenile Gyrfalcons stayed in its vicinity until late August. With a few exceptions, they remained within $5 \mathrm{~km}$ of the nest for about 40 days. After permanent dispersal, their movements seemed rather random, probably governed by the availability of prey. A study of juvenile Gyrfalcons in Alaska showed a similar pattern with no consistent directional movements (McIntyre et al. 2009). Like in Alaska, many of the Gyrfalcons ended up on the coast, presumably helping them to survive during their first winter because of greater availability of avian prey such as gulls, crows, and other coastal species. This may introduce increased mortality risks, as many wind-farms in Scandinavia are built in coastal areas. At Smøla wind-farm in Norway, juvenile Gyrfalcons are regular winter visitors, but so far none have been proven killed by turbines (Bevanger et al. 2011). Gyrfalcons in Norway are also often seen perching on pylons of the 22-kV power grid, and some of these structures are notorious bird-killers due to the short distance between the conductors and polemounted transformers (Bevanger et al. 2010).

The Gyrfalcon feeds mainly on ptarmigan, especially early in the breeding season, and its distribution is closely connected with the dis- tribution of ptarmigan species worldwide (Potapov and Sale 2005). The local availability of ptarmigan is believed to play an important role in both dispersal and survival of Gyrfalcons. Hunting statistics show that the number of ptarmigan bagged by hunters in the Fennoscandian mountains during the last decade has decreased steadily and dramatically. In Norway, the total bag decreased from c. half a million shot each year around the turn of the millennium to 164,000 ten years later. The number of registered hunters in the same period has been relatively constant (Statistics Norway 2010), and the number of birds bagged seems to correspond to the population sizes fairly well (H. C. Pedersen pers. comm.). Hunting pressure above $15 \%$ of the August stock will, as a rule, reduce populations of ptarmigan (Sandercock et al. 2010). Additional collision-mortality of ptarmigan induced by wind turbines as demonstrated at the windfarm on Smøla, Norway (Bevanger et al. 2011) could also reduce the prey base for Gyrfalcons. The relatively high numbers of falcons killed by wind-turbines in Germany indicates that the Gyrfalcon also could be at risk (Illner 2011). Being naïve, with imperfect flying skills, young Gyrfalcons will probably be more prone to collisions with man-made obstacles than older birds. Wind-farms could therefore be an 
additional risk if they were placed close to nesting sites. Placing wind-farms in ptarmigan habitat could increase risks and impact, directly during hunting flight, or indirectly through increased mortality of ptarmigan, causing reduced prey availability. Careful selection of sites for building wind-farms is essential to reduce the risk of collision between raptors and wind turbines.

We know the fate of only one of the juvenile Gyrfalcons (found dead $2.5 \mathrm{~km}$ from the nest and probably killed by an avian predator), but the fact that none of them transmitted signals through the first winter could indicate that the tags added stress and increased mortality. McIntyre (2009) suggested the same, and tagging results on Greenland were similar (Burnham 2007). A study of radio-tagged Prairie Falcons (Falco mexicanus) showed a negative effect on productivity (Steenhof et al. 2006). In contrast, no increased mortality has been observed on some satellite-tagged Peregrine Falcons (Falco peregrinus, Ganusevich et al. 2004; McGrady et al. 2002). The differences between these species and studies warrant investigation. The tag weight in our case was below the commonly accepted limit (1.5-3\% of body mass) which leaves the harness or transmitter design as potential problems. These should be investigated by studying birds in captivity.

\section{ACKNOWLEDGMENTS}

The project was financed by the Swedish Energy Agency under the Vindval programme at the Swedish Environmental Protection Agency. Additional funding for satellite tags was made available through the Swedish Ornithological Society, Alvins Foundation, and Olsson-Borghs Foundation. We would also like to thank Tomas Bergström, Alf Kjellström, Christer Edsholm, Göte Kjellström, Morgan Göransson, Marcus Göransson, Gudmund Söderin, and Nanna Söderin for invaluable field assistance.

\section{Literature Cited}

BAKKen, V., O. Runde, ANd E. TJøRVE. 2003. Norsk Ringmerkingsatlas, vol. I. Stavanger Museum, Stavanger, Norway.

Bevanger, K., G. BARTZKe, H. BrøSEth, E. L. Dahl, J. O. GJershaug, F. Hanssen, K. O. Jacobsen, P. Kvaløy, R. May, R. MeÅs, T. NYGÅRD, S. REFSNÆS, S. STOKKE, AND R. VANG. 2010. Optimal design and routing of power lines; ecological, technical and economic perspectives (OPTIPOL). NINA Rapport 619. Norsk institutt for naturforskning, Trondheim, Norway.

Bevanger, K., F. Berntsen, S. Clausen, E. L. Dahl, $\varnothing$. Flagstad, A. Follestad, D. Halley, F. Hanssen, L Johnsen, P. Kvaløy, P. Lund-Hoel, R. May, T. Nygård, H. C. Pedersen, O. Reitan, E. RøSkAFt, Y. STEINHEIM, B. StOKKE, AND R. VANG. 2010. Pre- and post-construction studies of conflicts between birds and wind turbines in coastal Norway (BirdWind). Report on findings 2007-2010. NINA Rapport 620. Norsk institutt for naturforskning, Trondheim, Norway.

BURNHAM, K. K. 2007. Inter- and intraspecific variation of breeding biology, movements, and genotype in Peregrine Falcon Falco peregrinus and Gyrfalcon F. rusticolus populations in Greenland. Ph.D thesis, University of Oxford, Oxford, UK.

Fransson, T., AND J. Pettersson. 2001. Svensk ringmärkningsatlas. Naturhistoriska riksmuseet; Sveriges Ornitologiska Förening, Stockholm, Sweden.

Ganusevich, S. A., T. L. Maechtle, W. S. SeEgar, M. A. Yates, M. J. McGrady, M. Fuller, L. Schueck, J. DAYton, AND C. J. HenNy. 2004. Autumn migration and wintering areas of Peregrine Falcons Falco peregrinus nesting on the Kola Peninsula, northern Russia. Ibis 146:291-297.

IllneR, H. 2011. Comments on the report "Wind Energy Developments and Natura 2000," edited by the European Commission in October 2010. Arbeitsgemeinschaft Biologischer Umweltschutz, Biologische Sta- 
tion Soest, Bad Sassendorf-Lohne, Germany.

McGrady, M. J., T. L. Maechtle, J. J. VarGas, W. S. Seegar, and M. C. P. Pena. 2002. Migration and ranging of Peregrine Falcons wintering on the Gulf of Mexico coast, Tamaulipas, Mexico. Condor 104:39-48.

McIntyre, C. L., D. C. Douglas, and L. G. ADAMS. 2009. Movements of juvenile gyrfalcons from western and interior Alaska following departure from their natal areas. Journal of Raptor Research 43:99-109.

Poole, K. 1989. Determining age and sex of nestling Gyrfalcons. Journal of Raptor Research 23:45-47.

Poole, K. G., AND R. G. BRomley. 1988. Natural history of the Gyrfalcon in the central Canadian Arctic. Arctic 41:31-38.

Potapov, E., AND R. SAle. 2005. The Gyrfalcon. T. \& A. D. Poyser, London, UK.
SAndercock, B. K., E. B. Nilsen, H. Brøseth, AND H. C. Pedersen. 2011. Is hunting mortality additive or compensatory to natural mortality? Effects of experimental harvest on the survival and cause-specific mortality of Willow Ptarmigan. Journal of Animal Ecology 80:244-258.

Smallwood, K. S., ANd B. Karas. 2009. Avian and bat fatality rates at old-generation and repowered wind turbines in California. Journal of Wildlife Management 73:1062-1071.

STATISTICS NORWAY. 2010. Rekordlav felling av ryper [Record low bags of ptarmigan]. http://www.ssb.no/srjakt/ Last updated 6 August 2010.

Steenhof, K., K. K. Bates, M. R. Fuller, M. N. Kochert, J. O. McKinley, And P. M. LUKACS. 2006. Effects of radiomarking on Prairie Falcons: Attachment failures provide insights about survival. Wildlife Society Bulletin 34:116-126. 